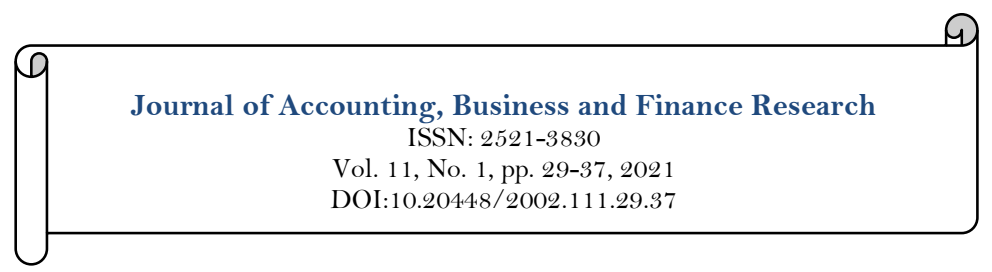

\title{
The Effect of Sustainability Report Disclosure and Innovations on Earnings Informativeness with Environmental Performance as a Moderating Variable
}

\author{
I Gusti Ayu Diah Dhyanasaridewi ${ }^{1 *}$ \\ Etty Murwaningsari ${ }^{2}$ \\ 1,2 Accounting Dept, Faculty of Economics and Business, University of Trisakti, Jakarta, Indonesia. \\ ${ }^{2}$ Email:diah.dhyanasari@gmail.com
}

\begin{abstract}
As climate change worsens, businesses must pay more attention to how their activities affect the environment. The aim of this current research is to analyze at the influence of environmental performance in moderating the relationship between sustainability reporting disclosure and earnings informativeness. A purposive sampling method was used to identify forty-two companies in the manufacturing and mining sectors listed on the Indonesia Stock Exchange (IDX) that follow the Program for the Assessment of Company Performance Ratings in Environmental Management (PROPER) consistently and published audited annual reports from 2017-2019. The absolute difference method was used to test the effect of the moderating variable, and SPSS 27 was used as a statistic analytical tool to analyze the hypothesis. The empirical test results indicate that environmental performance could weaken the effect of sustainability report disclosure on the informativeness of earnings, and it could also strengthen the influence of corporate innovation on earnings informativeness. On the other hand, environmental performance doesn't have a significant direct effect on the informativeness of earnings.
\end{abstract}

Keywords:

Sustainability reporting

Innovations

Earnings informativeness

Earning Response coefficient

Environmental performance.

JEL Classification:

C33; G11.

Licensed:

This work is licensed under a

Creative Commons Attribution 4.0

License.

Publisher:

Scientific Publishing Institute

Received: 25 January 2021 Revised: 16 February 2021

Accepted: 5 March 2021

Published: 29 March 2021

Corresponding Author)

Funding: This study received no specific financial support.

Competing Interests: The authors declare that they have no competing interests.

\section{Introduction}

Before deciding to invest in the capital market, investors will consider many things before deciding to invest in a company. Generally, investors will want to determine whether the company's financial performance is good or bad through its financial statements. The information contained in these statements is used by both internal and external parties for making business and investment decisions. Investors usually respond the most to information on earnings because it reflects the company's performance. The earnings response coefficient (ERC) can be used to see investor and creditor reactions in the capital market regarding financial statement disclosure.

Stock returns that relate to reporting quality can be measure by the ERC. A higher ERC value indicates that the investor is interested in earnings information disclosed by the company. However, information on earnings alone is sometimes not sufficient for making decisions because it is possible that the information is biased. Murwaningsari (2008) states that bias in earnings information is due to, among others, the untimely delivery of financial reports and the existence of earnings management practices as well as insufficient 
information disclosed in the financial statements. Apart from financial information, stakeholders also view the disclosure of non-financial information as an important factor in decision making (Assagaf, Murwaningsari, Gunawan, \& Mayangsari, 2019). Stakeholders require a company to have a sustainability strategy (Ernst \& Young, 2014). In general, more information is better than less. The more information that investors have, the more likely the company will be to experience excessive returns, as investors get a more complete picture of the company's vision. Sustainability reporting (SR) can be used to meet stakeholder expectations regarding the availability of sustainability performance information.

Sustainability reporting is an open practice used by organizations to report their impact on the economy, the environment and society. It includes their contribution to the objectives of sustainable development, either positive or negative. Internal and external stakeholders can form opinions and make decisions on the contribution of the organization to the objectives of sustainable development (Global Reporting Initiative, 2016). More sustainability information disclosed by a company indicates its willingness to be more informative. Stakeholders use additional information that is communicated through the Sustainability Report to reduce uncertainty, and it can help them better interpret and understand financial information (BonaSanchez, Perez-Aleman, \& Santana-Martin, 2017; Swarnapali, 2019b). Indonesia will have several challenges in the future regarding sustainability reports that need to be solved. Until today, despite the rapid growth of small and medium-sized enterprises in Indonesia, no one has reported on their contribution to economic, social and environmental development, and many of the companies listed on the Indonesian Stock Exchange have not published Sustainability Reports. The latest data from the Global Reporting Initiative (GRI) and the IDX shows that out of a total of 629 listed companies as of April 23, 2019, only 110 sustainability reports have been released (Liputan6.com, 2019).

Changes in the environment and technology rapidly happen, thus firms must increase their innovation capabilities. Canh, Liem, Thu, and Khuong (2019) argue that innovations are the main differentiators that enable a sustainable competitive advantage by modifying products (product innovation) or making alterations in production (process innovation). Any organization, large or small, will improve its innovation capabilities and maturity levels to attract investors. Some studies have proven that economic performance tends to be associated with innovation activities, although some researchers have reached different conclusions regarding the positive impact of innovations in products and processes on firm performance. Some argue that product innovation will be more efficient and will better support company performance, while other researchers argue otherwise (Klewitz \& Hansen, 2014; Mohnen \& Hall, 2013). Haapalainen and Kantola (2015); and West and Bogers (2014) argue that innovation may also involve, and occasionally need, collaboration or a joint effort with outsider stakeholders (open innovation).

Indonesia's high economic growth in recent years has not matched environmental standards. Indonesia still has a lot to improve, since compared to ASEAN countries, Indonesia's environmental performance is still far behind. According to the 2020 Environment Performance Index (EPI), Indonesia is ranked 116 out of 180 countries, while Singapore is ranked 39 and Malaysia is ranked 68 (Morse \& Morse, 2019). The EPI compiles and summarizes data on the sustainability of countries around the world. They rank 180 participating countries based on their environmental health and ecosystem quality using 32 performance indicators to measure how close they are to their environmental policy objectives at the national level.

The Indonesian government began implementing the Program for the Assessment of Company Performance Ratings in Environmental Management (PROPER) in 2002. This program intends to increase companies' awareness of environmental conservation. Five different colors - gold (best), green, blue, red and black (worst) - are awarded to companies based on their environmental performance. By looking at the colors, the public can see the environmental management level of a company. Based on the evaluation of 2,045 companies in 2018-2019, there were still two companies in the black category and 303 companies labelled as red. There were 1,507 blue companies, 174 green companies, and only 26 companies managed to get into the gold category.

The market response varies between each company due to phenomenon already discussed, including lack of non-financial disclosure, company environmental performance, and the type of innovation used to support and maintain a sustained competitive advantage. The research questions are: (a) Do sustainability reports affect earnings informativeness? (b) Does innovation affect earnings informativeness? (c) Does the relationship between the disclosure of sustainability reports and the informativeness of earnings moderate environmental performance? (d) Does the relationship between innovation and earnings informativeness moderate environmental performance?

Investors nowadays increasingly consider investing in companies that protect the environment. This research tries to further develop previous research by analyzing environmental performance as a moderator variable. Furthermore, it also adds control variables, such as company size, profitability, leverage, and growth opportunities. Various parties expected to benefit from this research include investors, issuers, and accounting professionals, as it provides insight regarding the disclosure of non-financial indicators, such as sustainability and innovation, which are two pieces of information that can be useful for analysis and investment decision making. 


\section{Literature Review \& Hypothesis Development 2.1. Signaling Theory}

Publishing a sustainability report is one way for companies to send positive signals to potential investors to influence their investment decisions in the capital market. In this research, signaling theory has been used to strengthen the analysis of the publication of sustainability reporting on the coefficient of response to earnings (ERC). Signaling theory is also related to information asymmetry because it assumes that each party will receive different information (Assagaf et al., 2019). In this case, information asymmetry occurs when one party possesses more material information about the organization than another party (Celani \& Singh, 2011). We use signaling theory to define the behavior of each party when they have access to different pieces of information

Over time, investors need information that can describe a company's performance more broadly and is not limited to financial reports. It is believed that information contained in sustainability reports could assist investors in making more concrete and rational decisions. A signal is a flow of information, and from a business point of view, it can be in the form of stock price information, dividend announcements, corporate social responsibility (CSR) programmes, environmental conservation programmes, etc. From a business perspective, it might be in the form of stock price information, dividend announcements, CSR programmes, environmental conservation programmes, etc. In this case, the one who acts as a signal provider is the insider (e.g., company management, executives, directors), and outsiders (individuals, investors, employees) who do not have access to the insider information will be the receivers. The interaction between providers and receivers is reflected in the feedback (Bae, Masud, \& Kim, 2018). The signaling theory indicates that sustainability or CSR reports are used by management to inform stakeholders, such as investors and potential investors, of the company's responsibility and sustainability management policy (Ching \& Gerab, 2017).

\subsection{The Informativeness of Earnings}

The informativeness of earnings is assessed by the earnings response coefficient (ERC), as stated by Mashayekhi and Aghel (2016). Scott (2015) defined the earnings response coefficient as an indicator of the level of abnormal returns on stocks in response to unexpected earnings components. The ERC is commonly used to evaluate the quality of good earnings. Different market responses to company earnings can be affected by profit persistence, profit quality, growth opportunities, beta, corporate capital structure, and price informativeness. There is a significant positive influence on the interaction between earnings persistence and earnings quality on the ERC value. That means the more persistent and better the earnings quality is, the higher the ERC value will be. But on the other hand, if the beta reflects a higher systematic risk, the ERC will be lower. We can see the stock price reaction to earnings through the ERC (Kothari \& Sloan, 1992). According to Herawaty (2018), a market player's confidence level on earnings quality can be measured by the market performance and the ERC. A low (high) level of the ERC shows a weak (strong) market reaction to earnings information, and those can indicate a bad (good) quality of earnings. In the context of company disclosures, Bona-Sanchez et al. (2017); ElBannan and Farooq (2019) argue that the power to explain earnings is higher in companies that disclose sustainability reporting. This means that the market players receive additional information to assess earnings through reporting communications.

\subsection{Sustainability Reporting Disclosure}

Sustainability reporting helps organizations to measure performance, set long-term goals, and make their operations more sustainable. It contains information about the organization's positive and negative impacts on environmental, social and governance (ESG) issues. The impact of sustainable development on organizational strategies and activities can be managed by understanding sustainability reporting (Haque \& Ntim, 2018). The underlying goal of sustainability reporting is to show how organizations contribute to improving economic, environmental, and social conditions at all levels, including local, regional, and global levels. Sustainability reporting is one of the essential corporate practices that has a recognized contribution to satisfying the diverse demands of stakeholders (Hahn \& Kühnen, 2013). Many standards-setting bodies, such as the Global Initiative for Sustainability Ratings (GISR), the Carbon Disclosure Project (CDP), and the Dow Jones Sustainability Index (DJSI) providing ratings to evaluate the impact on the environment. Meanwhile, other institutions provide guidance on the production of a sustainability report, such as the Organization for Economic Cooperation and Development (OECD), the United Nations Global Compact, the International Standard for Social Responsibility (ISO 26000), and the Global Reporting Initiative (GRI). The increased number of companies that use the GRI standards show that company awareness of the benefits of publishing a sustainability report has also increased (Bona-Sanchez et al., 2017). Market participants respond positively to companies that carry out sustainability disclosure. Since so much information is contained in sustainability reports, they complement financial data and help stakeholders to better interpret financial reporting. Sustainability disclosure enhances the informativeness of earnings by communicating the value of relevant information to capital market participants (Swarnapali, 2019b). Based on that, we propose the first hypothesis:

\section{H1: Sustainability reporting has a significant positive effect on the informativeness of earnings.}




\subsection{Innovation}

Innovation is a concept that is difficult to understand because it encompasses a range of activities and results. One of the generally accepted definitions, referring to OECD/Eurostat (2018), is that an innovation is a brand new or enhanced product and/or process that significantly differs from the previous product.

Innovations from an economic perspective can create new jobs, but on the other hand, innovation also has a dark side in the economy. Gârleanu, Kogan, and Panageas (2012) argue that existing workers in a firm are under more pressure and can reduce firm profit. Gu (2005) and Jia (2018) argue that a company with an exploration-oriented strategic innovation plan is even more sensitive to falling share prices compared to an exploitation-oriented strategy innovation. Innovation activities, such as creating new products and new processes in a short space of time, can win customer loyalty and boost company performance, but also require time to make a positive change in firm profitability. Canh et al. (2019) argue that sometimes innovation requires collaborations with people or organizations outside the company (open innovation), such as collaborations with researchers in universities, with other companies, or by participating in an innovation ecosystem. Furthermore, based on the literature, we aim to analyze the relation process, product, and open innovation on earnings informativeness. A company's innovation, either product or process innovation, has been reported to have a significant positive impact on its performance, according to Canh et al. (2019). Specifically, they suggest that it can make products or services in terms of features or price more attractive to consumers. Innovation can help a company to maintain market share and be more competitive. The second hypothesis based on the above is:

H2: Innovation has a positive effect on earnings informativeness.

\subsection{Environmental Performance}

The companies' environmental performance is measured through environmental management ratings (PROPER) held by the Indonesian government (Ministry of Environment and Forestry) and the companies' level of compliance based on applicable regulations. These ratings are regularly announced to the public, so there will be reputation incentives or disincentives depending on the level of compliance. The Indonesian Ministry of Environment and Forestry has been assessing company performance ratings in environmental management since 1995. The business and/or activity performance rating consists of five different colors: Gold is for companies that consistently demonstrate excellence in environmental management; Green is for companies that have exceeded compliance requirements in environmental management; Blue is for companies that have complied with the regulation requirements; Red indicates that a business has not complied with the regulation requirements; and Black denotes companies with no environmental management and that deliberately commit acts of neglect that contaminate and damage the environment. The public will know the company's level of compliance by looking at their color ratings. Herawaty (2018) stated that environmentally friendly companies will attract more investors as they tend to disclose more information to market participants. As long as they keep improving their environmental performance, the company value will also increase. Based on the above, the third hypothesis proposed is:

H3: Environmental performance strengthens the effect of sustainability reporting on the informativeness of earnings.

According to Wahyudianto and Boedisantoso (2017), the application of PROPER is a successful evaluation tool for environmental management and a trigger for sustainable industrial technology innovation. Successful innovations are shown by the increase in environmental performance; therefore, the fourth hypothesis is:

H4. Environmental performance strengthens the influence of innovation on the informativeness of earnings.

\section{Research Methodology}

\subsection{Sample Selection and Data Collection}

The entire sample population comprises companies in the manufacturing and mining industries listed on the IDX. For the sample collection, a purposive sampling method was used, which identified 126 firm years from 42 companies that consistently followed the PROPER assessment over a three-year period (2017-2019). Secondary data were collected in the form of annual reports, which were downloaded from the IDX website, and sustainability reports, which were downloaded from the companies' websites.

\subsection{Variable Measurement}

\subsubsection{Earnings Response Coefficient}

Earnings informativeness as a dependent variable in this research is assessed using the earnings response coefficient (ERC). The measurement is done in stages formulated by Assagaf et al. (2019) and Murwaningsari (2008). The regression coefficient $(\alpha 1)$ in the equation below is the ERC coefficient.

$$
\text { CAR it }(-5,+5)=\boldsymbol{\alpha O}+\alpha 1 \text { UEit }+ \text { eit }
$$


In Equation 1, $\mathrm{CAR}_{\mathrm{i}, \mathrm{t}(-5,+5)}$ is the cumulative abnormal return of company $\mathrm{i}$ in year $\mathrm{t}$, and in a period of \pm 5 days from the declaration of the financial statement report. $\boldsymbol{\alpha o}$ indicates a constant, $\boldsymbol{\alpha} \mathbf{1}$ is the ERC coefficient, UEit is a firm's unexpected earnings in years $t$, and cit is the error component. The first step is the calculation of the cumulative abnormal return (CAR). Based on Assagaf et al. (2019); Herawaty (2018); and Murwaningsari (2008), we used 11 days as a window (time interval), which is five days before (-5) and five days after $(+5)$ the date $(0)$ that a company submits its financial reporting. The CAR is formulated as follows:

$$
\begin{aligned}
& \boldsymbol{C A R} i, t(-5,+5)=\sum_{t=+5}^{t=-5} \boldsymbol{A R} i, t \\
& \boldsymbol{A R} i . t=\boldsymbol{R} i, t-\boldsymbol{R M} t \\
& \boldsymbol{R} i, t=\frac{\text { Pi,t-Pi,t-1 }}{\text { Pi,t-1 }} \\
& \boldsymbol{R} \boldsymbol{m}, t=\frac{\text { IHSG }- \text { IHSG }-1}{\text { IHSGt }-1}
\end{aligned}
$$

In Equations $2-5, \mathbf{A} \mathbf{R}_{\mathrm{i}, \mathrm{t}}$ indicates the abnormal return of company i in year $\mathrm{t} ; \mathbf{R}_{\mathrm{i}, \mathrm{t}}$ is the actual return of shares from company $\mathrm{i}$ in year $\mathrm{t} ; \mathbf{R} \mathbf{M}_{\mathrm{t}}$ is the market return in year $\mathrm{t}$; $\mathbf{P}_{\mathrm{i}, \mathrm{t}}$ is the closing price of stock $\mathrm{i}$ on day $\mathrm{t}$; $\mathbf{P}_{\mathrm{i}, \mathrm{t}-1}$ is the closing price of stock i on day $\mathrm{t}-1$; $\mathbf{I H S G}_{\mathrm{t}}$ is the composite stock price index on day $\mathrm{t}$; $\mathbf{I H S G}_{\mathrm{t}-1}$ is the composite stock price index on day $\mathrm{t}-1$.

The next step is to compute the unexpected earnings (UE) as a result of change throughout the company's earnings per share in the current year minus the company's earnings per share in the previous year, divided by price per share in the previous year. Equation 6 calculates the unexpected earnings:

$$
\boldsymbol{U E} i, t=\frac{E P S i, t-E P S i, t-1}{P i, t-1}
$$

Where:

$\mathbf{U E}_{\mathrm{i}, \mathrm{t}}$ is the unexpected earnings of firm $\mathrm{i}$ in year $\mathrm{t}$; $\mathbf{E P S}_{\mathrm{i}, \mathrm{t}}$ is the earnings per share of firm $\mathrm{i}$ in year $\mathrm{t}$; $\mathbf{E P S}_{\mathrm{i}, t-1}$ is the earnings per share of firm $\mathrm{i}$ in year $\mathrm{t}-1$; and $\mathbf{P}_{\mathrm{i}, \mathrm{t}-1}$ is the price per share of the previous year.

The last step is to regress the cumulative abnormal return (CAR) and the unexpected earnings (UE) to determine the value of the earnings response coefficient (ERC).

\subsubsection{Sustainability Disclosure}

In this study, sustainability disclosure includes the economic, environmental and social dimensions. By following prior studies (e.g., Mahmood \& Orazalin, 2017), we developed a sustainability reporting (SR) dimension measurement based on a content analysis approach and use a value of 1 if the corresponding information is declared, and o otherwise. Specifically, we quantify sub-indices for economic, environmental and social sustainability indicators through the application of internationally recognized GRI guidelines and standards. We therefore follow the GRI reporting standards, which consist of 86 topic-specific items, including economic (13 items), environmental (33 items), and social (40 items). The formula for the calculation of the score index for each dimension, based on Rachmawati (2017) and Tarigan \& Semuel (2015), is as follows:

\section{Index $=n / k$}

In Equation 7, Index is the disclosure score, $\boldsymbol{n}$ is the number of items disclosed, and $\boldsymbol{k}$ represents the number of items expected to be disclosed (86 items).

\subsubsection{Innovation}

Three aspects of innovation are investigated: product, process, and whether the activities are open or closed innovation. In order to measure product innovation activities, we use a dummy variable that is given a value of 1 if significant or minor product improvements have been made or new products have been introduced to the market in the respective year, and o otherwise (Canh et al., 2019; Slater, Mohr, \& Sengupta, 2014). Process innovation is measured with a dummy variable that is given a value of 1 if significant or minor process improvements have been introduced or a new process has been devised for production and/or product delivery, and o otherwise (Canh et al., 2019; Slater et al., 2014). Open innovation receives a value of 1 if firms innovate with the support of external organizations, and 0 if their innovative activities rely solely on their internal R\&D efforts without any support from external organizations; this is consistent with Zhang, Yang, Qiu, Bao, and Li (2018).

\subsubsection{Environmental Performance}

Based on research by Rakhiemah and Agustia (2012), a score is given to a company's PROPER rating to measure its environmental performance. The PROPER performance rating system allocates a color to companies based on their environmental management performance: Gold (excellent) = 5; Green (very good) $=$ 4; Blue $($ good $)=3 ; \operatorname{Red}($ bad $)=2 ;$ and Black $($ very bad $)=1$. 


\subsubsection{Control Variable}

The control variable is used to increase the adjusted R-squared value so that the model becomes more robust. There are some control variables which will be examined to assess their relationship with the dependent variable, such as firm leverage (LEV), that may influence the earnings informativeness evaluated by the debt-to-equity ratio, which can be calculated by dividing the total liabilities of the company by its equity (ElBannan \& Farooq, 2019). The effect of growth opportunities (GRW) on ERC is controlled by the price-tobook value (PBV), which is calculated by the ratio of a company's stock market price above its book value of equity. This study also used profitability determined by the return on assets (ROA), which is calculated by dividing the net income by the total assets and shown as a percentage (\%). To control the effect of firm size (SIZE) on the informativeness of earnings, this paper used the log of the total assets (Assagaf et al., 2019).

\subsection{Data Analysis Methods}

This paper includes the analysis of panel data with a multiple linear regression method. The equation for Hypotheses 1 and 2 is as follows:

$$
\text { ERC it }=\alpha+\beta_{1} \text { SRD it }+\beta_{2} \text { INOV it }+\beta_{3} \text { LEV it }+\beta_{4} \text { GRW it }+\beta_{5} \text { ROA it }+\beta_{6} \text { SIZE it }+\varepsilon
$$

To analyze the moderating variable, Frucot \& Shearon (1991) proposed a slightly different regression model to test the effect of moderation, namely the absolute difference value model of the independent variables.

The equations for Hypotheses 3 and 4 are as follows:

$$
\mathrm{ERC}_{\mathrm{it}}=\alpha+\beta_{1} \mathrm{SRD}_{\mathrm{it}}+\beta_{2} \mathrm{PROPER}_{\mathrm{it}}+\beta_{3}\left|\mathrm{SRD}_{\mathrm{PROPE}}\right|_{\mathrm{it}}+\beta_{4} \mathrm{LEV}_{\mathrm{it}}+\beta_{5} \mathrm{GRW}_{\mathrm{it}}+\beta_{6} \mathrm{ROA}_{\mathrm{it}}+\beta_{7} \mathrm{SIZE}_{\mathrm{it}}+\varepsilon
$$

$\mathrm{ERC}_{\mathrm{it}}=\alpha+\beta_{1}$ INOVit $+\beta_{2}$ PROPERit $+\beta 3 \mid$ INOV-PROPER $\mid$ it $+\beta_{4}$ LEVit $+\beta_{5}$ GRWit $+\beta_{6}$ ROAit $+\beta_{7} \mathrm{SIZE}_{\mathrm{it}}+\varepsilon$ (3)

Where $\mathbf{E R C}_{\text {it }}$ is the earnings response coefficient of company i in year t; $\mathbf{S R D}_{\text {it }}$ is the sustainability report disclosure of company i in year t; $\mathbf{I N O V}_{\text {it }}$ indicates the innovation of company i in year t; PROPER $\mathbf{P R}_{\text {it }}$ is the environmental performance score of company $i$ in year $t ; \mathbf{L E V}_{\text {it }}$ is the leverage of company i in year $t$; $\mathbf{G R W}_{\text {it }}$ is

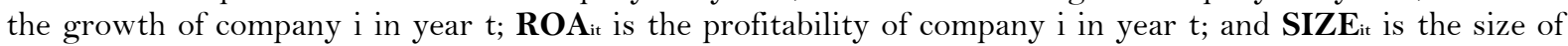
company $\mathrm{i}$ in year $\mathrm{t}$.

\section{Results and Discussion}

The descriptive statistics are provided in Table 1. The ERC average value is 0.000 , and the average total sustainability disclosure score is $50.33 \%$, indicating that the manufacturing and mining sectors still need to improve their disclosure.

Table 1. Descriptive Statistics.

\begin{tabular}{l|c|c|c|c|c}
\hline & $\mathbf{N}$ & Min. & Max. & Mean & SD \\
\hline Dependent variable & 126 & -0.44 & 0.55 & 0.0000 & 0.1360 \\
\hline ERC & \multicolumn{5}{l}{} \\
\hline Independent variables & 126 & 0.23 & 0.837 & 0.5033 & 0.1644 \\
\hline SRD & 126 & 2 & 3 & 2.60 & 0.4930 \\
\hline INOV & 126 & & 3.07 & 0.5540 \\
\hline Moderating variable & 126 & 2 & 5 & & \\
\hline PROPER & \multicolumn{5}{|l}{} \\
\hline Control variables & 126 & 26.93 & 32.01 & 29.396 & 1.3684 \\
\hline SZ & 126 & -0.10 & 0.53 & 0.0809 & 0.1044 \\
\hline ROA & 126 & -0.15 & 11.05 & 1.3542 & 1.7553 \\
\hline GRW & 126 & 0.02 & 12.36 & 1.0323 & 1.6085
\end{tabular}

The average value for innovation is 2.6, and the average score for PROPER is 3.07, which indicates that firms in the manufacturing and mining sectors overall have good (blue) environmental performance. The mean values for the sustainability disclosure, innovation, environmental performance and size variables are greater than the standard deviation, which indicates that the data distribution is homogeneous. The mean values for $\mathrm{ERC}$, profitability, and leverage are less that the standard deviation, which indicates heterogenous data distribution.

Table 2 displays the variables' correlation coefficients. The ERC is positively and significantly correlated with SRD $(\rho<0.05)$, INOV and GRW $(\rho<0.01)$. A positive and insignificant correlation was also found between SRD and SIZE $(\rho<0.01)$. In addition, a negative and insignificant association was found between INOV and GRW. 
Table 2. Spearman's Rho Correlation.

\begin{tabular}{|c|c|c|c|c|c|c|c|c|}
\hline & SRD & INOV & PROPER & ERC & SZ & ROA & GRW & LEV \\
\hline \multirow[t]{2}{*}{ SRD } & 1.000 & 0.095 & $0.391^{* * *}$ & $0.181^{*}$ & $0.595^{* * *}$ & 0.111 & -0.086 & -0.149 \\
\hline & & 0.288 & 0.000 & 0.042 & 0.000 & 0.215 & 0.340 & 0.095 \\
\hline \multirow[t]{2}{*}{ INOV } & & 1.000 & 0.054 & $0.260^{* * *}$ & -0.010 & $0.210^{*}$ & $-0.259^{* * *}$ & -0.086 \\
\hline & & & 0.551 & 0.003 & 0.913 & 0.018 & 0.003 & 0.339 \\
\hline \multirow[t]{2}{*}{ PROPER } & & & 1.000 & 0.049 & $0.457^{* * *}$ & $0.405^{* *}$ & -0.023 & $-0.178^{*}$ \\
\hline & & & & 0.588 & 0.000 & 0.000 & 0.800 & 0.046 \\
\hline \multirow[t]{2}{*}{ ERC } & & & & 1.000 & 0.006 & 0.020 & $0.463^{* * *}$ & -0.062 \\
\hline & & & & & 0.946 & 0.823 & 0.000 & 0.488 \\
\hline \multirow[t]{2}{*}{ SIZE } & & & & & 1.000 & $0.247^{* *}$ & 0.166 & -0.034 \\
\hline & & & & & & 0.005 & 0.063 & 0.703 \\
\hline \multirow[t]{2}{*}{$\mathrm{ROA}$} & & & & & & 1.000 & 0.042 & $-0.392^{* * *}$ \\
\hline & & & & & & & 0.639 & 0.000 \\
\hline \multirow[t]{2}{*}{ GROWTH } & & & & & & & 1.000 & $-0.216^{*}$ \\
\hline & & & & & & & & 0.015 \\
\hline LEV & & & & & & & & 1.000 \\
\hline
\end{tabular}

Table 3 presents the regression results for hypotheses 1 and 2. Our model's explanatory power is $8.9 \%$, which is relatively low but is still acceptable in accounting research. The empirical research shows that sustainability report disclosure has no significant effect on the ERC. This outcome is not in line with BonaSanchez et al. (2017) and Swarnapali (2019b). In this case, hypothesis 1 is rejected. On the other hand, researchers found a significant positive association between innovation and the ERC $(\rho<0.05)$, so hypothesis 2 is accepted.

Table 3. Empirical Results for Hypotheses $1 \& 2$.

\begin{tabular}{c|c|c|c}
\hline Variable & Prediction & Coefficient & P-value \\
\hline SRD & + & 0.022 & 0.801 \\
\hline INOV & + & 0.059 & $0.019^{* *}$ \\
\hline LEV & - & -0.019 & $0.014^{* *}$ \\
\hline GRW & + & 0.013 & $0.062^{*}$ \\
\hline ROA & + & -0.127 & 0.283 \\
\hline SZ & + & 0.003 & 0.779 \\
\hline Adj. R & & & \\
\hline
\end{tabular}

Note: ** denotes that the P-value is significant at the 0.05 level (2-tailed); * denotes that the P-value is significant at the 0.10 level (2-tailed).

These findings are in line with Canh et al. (2019). Regarding the control variable, a negative relationship was found between leverage $(\rho<0.05)$ and the $\mathrm{ERC}$, and a positive significant relationship was found between growth $(\rho<0.10)$ and the ERC. Other control variables, such as profitability and size, did not have a significant effect on the ERC.

The results for hypotheses 3 and 4 are presented in Table 4 . They show that PROPER_SRD has a significant effect $(\mathrm{sig} 0.003<0.05)$. These results indicate that environmental performance moderates the relationship between sustainability report disclosure and the ERC in a negative direction (-0.53). We can also say that environmental performance weakens the relation between SRD and the ERC. On the other hand, environmental performance moderates the relationship between SRD and the ERC $(\operatorname{sig} 0.03<0.5)$ in a positive direction (0.38). It also shows that environmental performance strengthens the relationship between innovation and SRD.

Table 4. Empirical Results for Hypotheses 3 \& 4.

\begin{tabular}{l|c|c}
\hline \multicolumn{1}{l}{ Table 4. Empirical Results for Hypotheses 3 \& 4. } \\
\hline Variable & Coefficient & P-value \\
\hline SRD & 0.003 & 0.854 \\
\hline INOV & 0.034 & $0.006^{* *}$ \\
\hline PROPER & -0.011 & 0.435 \\
\hline PROPER_SRD & -0.053 & $0.003^{* *}$ \\
\hline PROPER_INOV & 0.038 & $0.030^{* *}$ \\
\hline SZ & 0.006 & 0.560 \\
\hline ROA & -0.032 & 0.793 \\
\hline LEV & -0.012 & $0.071^{*}$ \\
\hline GRW & 0.022 & $0.003^{* *}$ \\
\hline Adj. R2 & 0.154 & \\
\hline N
\end{tabular}

Note: ** denotes that the P-value is significant at the 0.05 level (2-tailed); * denotes that the P-value is significant at the 0.1 level (2tailed). 


\section{Conclusion, Limitation and Future Research}

The relationship between the information level of sustainability reporting disclosure and earnings informativeness is still diverse. Theoretically, according to Bona-Sanchez et al. (2017), the relationship between disclosure (both mandatory and voluntary sustainability disclosure) and the informativeness of earnings is positive. Sustainability reports are a media to communicate with investors, to reduce information asymmetry when profit information gives less information about firm value (Cantele, Tsalis, \& Nikolaou, 2018; Imoniana, Soares, \& Domingos, 2018). The research findings indicate that investors do not rely on the information disclosed in a company's sustainability report since most companies in the manufacturing and mining sectors in Indonesia have not yet published a sustainability report. The empirical findings reveal that environmental performance can weaken the relationship between SRD and the ERC. The manufacturing and mining sectors have crucial roles in their contribution to domestic income and employment rate. Specifically, product, process, and open innovations can support firm sustainability in this era of digitalization, and innovation strategies help firms to maintain and increase their competitiveness in the global market.

Due to the short study period of three years, this research can't determine the long-term effect of firms' innovation activities on earnings informativeness. Recommendations for future research include studying different types of organizations and using data over a longer timeframe.

\section{References}

Assagaf, A., Murwaningsari, E., Gunawan, J., \& Mayangsari, S. (2019). Factors affecting the earning response coefficient with real activities earning management as moderator: Evidence from Indonesia stock exchange. Asian Journal of Economics, Business and Accounting, 11(2), 1-14. https://doi.org/10.9734/ajeba/2019/v1 1i230124

Bae, S. M., Masud, M. A. K., \& Kim, J. D. (2018). A cross-country investigation of corporate governance and corporate sustainability disclosure: A signaling theory perspective. Sustainability, 10(8), 1-16. https://doi.org/10.3390/su10082611

Bona-Sanchez, C., Perez-Aleman, J., \& Santana-Martin, D. J. (2017). Sustainability disclosure, dominant owners and earnings informativeness. Research in International Business and Finance, 39, 625-639. https://doi.org/10.1016/j.ribaf.2016.07.020

Canh, N. T., Liem, N. T., Thu, P. A., \& Khuong, N. V. (2019). The impact of innovation on the firm performance and corporate social responsibility of Vietnamese manufacturing firms. Sustainability, 11(13), 1-14. https://doi.org/10.3390/su11133666

Cantele, S., Tsalis, T. A., \& Nikolaou, I. E. (2018). A new framework for assessing the sustainability reporting disclosure of water utilities. Sustainability, 1O(2), 1-12. https://doi.org/10.3390/su10020433

Celani, A., \& Singh, P. (2011). Signaling theory and applicant attraction outcomes. Personnel Review, 40(2), 222-238. https://doi.org/10.1108/00483481111106093

Ching, H., \& Gerab, F. (2017). Sustainability reports in Brazil through the lens of signaling, legitimacy and stakeholder theories. Social Responsibility Journal, 13(1), 95-110. https://doi.org/10.1 108/srj-10-2015-0147

ElBannan, M. A., \& Farooq, O. (2019). When are earnings informative? Effect of stock liquidity on value of reported earnings in an emerging market: Evidence from Egypt. International Journal of Islamic and Middle Eastern Finance and Management, 12(3), 388-406. https://doi.org/10.1108/imefm-08-2018-0270

Ernst, \& Young. (2014). Sustainability reporting - the time is now. EY.Com. Retrieved from: https://www.eycom.ch/en/Publications/20141028-Sustainability-reporting-the-time-is-now.

Frucot, V., \& Shearon, W. T. (1991). Budgetary participation, locus of control, and Mexican managerial performance and job satisfaction. The Accounting Review, 66(1), 80-99.

Gârleanu, N., Kogan, L., \& Panageas, S. (2012). Displacement risk and asset returns. Journal of Financial Economics, 105(3), 491-510. https://doi.org/10.1016/j.jfineco.2012.04.002

Global Reporting Initiative. (2016). Gri 101: Landasan 2016. Retrieved from: https://www.globalreporting.org/standards/download-the-standards/.

Gu, F. (2005). Innovation, future earnings, and market efficiency. Journal of Accounting, Auditing \& Finance, 20(4), 385-418. https://doi.org/10.1177/0148558x0502000405

Haapalainen, P., \& Kantola, J. (2015). Taxonomy of knowledge management in open innovations. Procedia Manufacturing, 3, 688-695. https://doi.org/10.1016/j.promfg.2015.07.307

Hahn, R., \& Kühnen, M. (2013). Determinants of sustainability reporting: A review of results, trends, theory, and opportunities in an expanding field of research. Journal of Cleaner Production, 59, 5-21. https://doi.org/10.1016/j.jclepro.2013.07.005

Haque, F., \& Ntim, C. G. (2018). Environmental policy, sustainable development, governance mechanisms and environmental performance. Business Strategy and the Environment, 27(3), 415-435. https://doi.org/10.1002/bse.2007

Herawaty, V. (2018). The effect of environmental performance and accounting characteristics to earnings informativeness. IOP Conference Series: Earth and Environmental Science, 106(1), 012077. https://doi.org/10.1088/1755$1315 / 106 / 1 / 012077$

Imoniana, J. O., Soares, R. R., \& Domingos, L. C. (2018). A review of sustainability accounting for emission reduction credit and compliance with emission rules in Brazil: A discourse analysis. Journal of Cleaner Production, 172, 20452057. https://doi.org/10.1016/j.jclepro.2017.11.217

Jia, N. (2018). Corporate innovation strategy and stock price crash risk. Journal of Corporate Finance, 53, $155-173$. https://doi.org/10.1016/j.jcorpfin.2018.10.006

Klewitz, J., \& Hansen, E. G. (2014). Sustainability-oriented innovation of SMEs: A systematic review. Journal of Cleaner Production, 65, 57-75. https://doi.org/10.1016/j.jclepro.2013.07.017 
Kothari, S. P., \& Sloan, R. G. (1992). Information in prices about future earnings: Implications for earnings response coefficients. Journal of Accounting and Economics, 15(2-3), 143-171.

Liputan6.com. (2019). IDX encourages listed companies to implement sustainable development. Retrieved from: https://www.liputan6.com/bisnis/read/3950084/bei-dorong-perusahaan-tercatat-terapkan-pembangunanberkelanjutan.

Mahmood, M., \& Orazalin, N. (2017). Green governance and sustainability reporting in Kazakhstan's oil, gas, and mining sector: Evidence from a former USSR emerging economy. Journal of Cleaner Production, 164, 389-397. https://doi.org/10.1016/j.jclepro.2017.06.203

Mashayekhi, B., \& Aghel, Z. L. (2016). A study on the determinants of earnings response coefficient in an emerging market. International Journal of Economics and Management Engineering, 10(7), 2479-2482.

Mohnen, P., \& Hall, B. H. (2013). Innovation and productivity: An update. Eurasian Business Reviere, 3(1), 47-65.

Morse, S., \& Morse, S. (2019). Environmental performance index. The Rise and Rise of Indicators, 102-123. https://doi.org/10.4324/9781315226675-5

Murwaningsari, E. (2008). Pengujian simultan: beberapa faktor yang mempengaruhi earning response coefficient (ERC). Paper presented at the Accounting National Symposium.

OECD/Eurostat. (2018). Oslo manual 2018: Guidelines for collecting, reporting and using data on innovation the measurement of scientific, technological and innovation activities. In Handbook of Innovation Indicators and Measurement (4th ed.). Retrieved from: https://www.oecd-ilibrary.org/science-and-technology/oslo-manual2018_9789264304604-en.

Rachmawati, S. (2017). Effect of voluntary disclosure and corporate social responsibility disclosure on earnings response coefficient. Media Riset Akuntansi, Auditing \& Informasi, 16(2), 141-160.

Rakhiemah, A. N., \& Agustia, D. (2012). The influence of environmental performance on corporate social responsibility (CSR) disclosure and financial performance of registered manufacturing companies in Indonesia (pp. 1-31): Airlangga University.

Scott, W. R. (2015). Financial accounting theory. In Financial Accounting Theory (7th ed.): United States: Canada Cataloguing.

Slater, S. F., Mohr, J. J., \& Sengupta, S. (2014). Radical product innovation capability: Literature review, synthesis, and illustrative research propositions. Journal of Product Innovation Management, 31(3), 552-566. https://doi.org/10.1111/jpim.12113

Swarnapali, R. N. C. (2019b). Sustainability disclosure and earnings informativeness: evidence from Sri Lanka. Asian Journal of Accounting Research, 33-46. https://doi.org/10.1 108/ajar-05-2019-0033

Tarigan, J., \& Semuel, H. (2015). Disclosure of sustainability report and financial performance. Journal of Accounting and Finance, 16(2), 88-101. https://doi.org/10.9744/jak.16.2.88-101

Wahyudianto, F. E., \& Boedisantoso, R. (2017). PROPER application as a tool to trigger sustainable industrial technology innovation. IPTEK Journal of Proceedings Series(2). https://doi.org/10.12962/j23546026.y2018i1.3347

West, J., \& Bogers, M. (2014). Leveraging external sources of innovation: A review of research on open innovation. Journal of Product Innovation Management, 31(4), 814-831. https://doi.org/10.1111/jpim.12125

Zhang, S., Yang, D., Qiu, S., Bao, X., \& Li, J. (2018). Open innovation and firm performance: Evidence from the Chinese mechanical manufacturing industry. Journal of Engineering and Technology Management, 48, 76-86. https://doi.org/10.1016/j.jengtecman.2018.04.004 